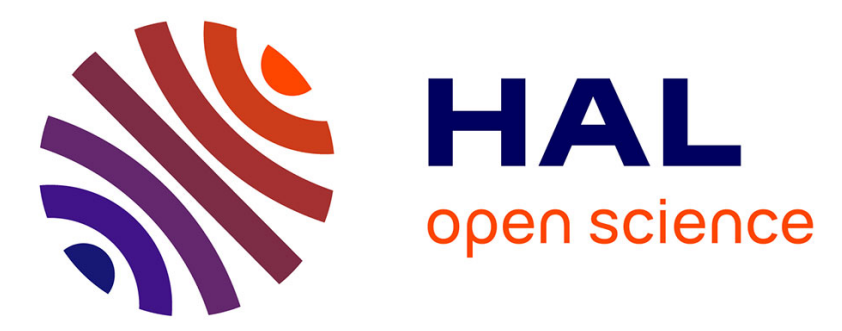

\title{
Contemporary Rāhui: Placing Indigenous, Conservation, and Sustainability Sciences in Community-led Conservation
}

\author{
Pauline Fabre, Tamatoa Bambridge, Joachim Claudet, Eleanor Sterling, \\ Alexander Mawyer
}

\section{To cite this version:}

Pauline Fabre, Tamatoa Bambridge, Joachim Claudet, Eleanor Sterling, Alexander Mawyer. Contemporary Rāhui: Placing Indigenous, Conservation, and Sustainability Sciences in Community-led Conservation. Pacific conservation Biology, 2021, 10.1071/PC20087 . hal-03476900

\section{HAL Id: hal-03476900 https://hal.science/hal-03476900}

Submitted on 13 Dec 2021

HAL is a multi-disciplinary open access archive for the deposit and dissemination of scientific research documents, whether they are published or not. The documents may come from teaching and research institutions in France or abroad, or from public or private research centers.
L'archive ouverte pluridisciplinaire HAL, est destinée au dépôt et à la diffusion de documents scientifiques de niveau recherche, publiés ou non, émanant des établissements d'enseignement et de recherche français ou étrangers, des laboratoires publics ou privés. 

Community-led Conservation

Pauline Fabre $^{\mathrm{A}, \mathrm{F}}$, Tamatoa Bambridge ${ }^{\mathrm{B}}$, Joachim Claudet $^{\mathrm{C}}$, Eleanor Sterling ${ }^{\mathrm{D}}$ and Alexander Mawyer ${ }^{(D)} \mathrm{E}$

A École Pratique des Hautes Études, PSL Paris University, CRIOBE, USR 3278 CNRS-EPHE-UPVD, BP 101398729 Papetoai Moorea - French Polynesia.

${ }^{B}$ PSL Paris University: EPHE-UPVD-CNRS, USR 3278 CRIOBE, Laboratoire d'Excellence

" CORAIL », BP 1013 Papetoai, 98729 Moorea, French Polynesia.

${ }^{C}$ National Center for Scientific Research, PSL Université Paris, CRIOBE, USR 3278

CNRS-EPHE-UPVD, Maison des Océans, 195 rue Saint-Jacques, 75005 Paris, France.

${ }^{\mathrm{D}}$ Center for Biodiversity and Conservation, American Museum of Natural History, 200 Central Park West, New York, NY 10024, USA.

${ }^{E}$ Center for Pacific Islands Studies, University of Hawai'i at Mānoa, 1890 East-West Road,

Moore Hall 210, Honolulu, HI 96822, USA.

${ }^{\mathrm{F}}$ Corresponding author. Email: fabre.plc@gmail.com

\begin{abstract}
Resource sustainability requires recognizing and developing pathways to integrate local and Indigenous knowledges alongside conservation and sustainability sciences within management practices and governance. However, knowledge never occurs in a vacuum and is always mediated by the beliefs, values, or stances towards its possession or use within particular contexts. Focusing on the unprecedented renewal of a traditional practice of natural resource management in French Polynesia called rāhui, this article investigates the local conceptions, perceptions, and expectations (CPE) which mediate between community knowledges, plans, and actions, and inputs from conservation and sustainability sciences. Drawing on a multi-year ethnographic study focused on the CPE of two coastal communities around Tahiti's Taiarapu coast, our results show that the CPE which shape relationships between conservation sciences' inputs toward decision and policy-making and community governance and management over nearshore marine resources can differ meaningfully. Moreover, we suggest that evidence of such differences despite socioeconomic, cultural, or demographic similarities indicates that the specificities of local communities' CPE around conservation and sustainability sciences should be carefully considered before and alongside any conservation or management action.
\end{abstract}

Keywords: conservation science, community-led governance, conception, perception, Taiarapu, French Polynesia

\title{
Introduction
}

The neighboring district of Tautira rejected the rāhui for a long time. However, when I arrived in Taiarapu, I watched it being born. I saw trust building up over the meetings between local community and the team of scientists to which I still belong. And I met this resident. He was not a fisherman but a significant consumer of fish. He collected signatures, he explained to residents what the rāhui had to offer them. One day, he brought me to the church to chat with the community, residents of the Fenua 
'Aihere (the rural part of the island past the end of the road). As soon as I arrived a fisherman lectured me: "I recognize you [from the rāhui meetings] ... how are we going to feed our family if we can no longer fish? Who is going to do our job? This is not good for us." He went on with his speech, "But I know what you do is for our children. I am glad you are here with us." (Fabre, fieldnote excerpt) ${ }^{1}$

Accelerated global environmental change, including climate change, rapid loss of biodiversity, scarcity of resources, and massive shifts in land and sea use, has ushered in a new era, conventionally referred to as the Anthropocene (Norström et al. 2016, Berkes 2017, Russell and Kueffer 2019), which calls for new tools towards the sustainable governance and management of resources with a strident urgency. The problem is particularly critical in island ecosystems. Where community well-being that depends on natural resources is directly impacted, rapid solutions are needed (Graham et al. 2017, McMillen et al. 2017, Friedlander 2018). Among attempts to achieve sustainability in this new era of global changes, the recognition and inclusion of Indigenous and local knowledge alongside or integrated with conservation or sustainability sciences has increasingly become a key focus for work on resource management process and governance systems (Moller et al. 2004, Plummer et al. 2013, McMillen et al. 2014, Lauer 2017, Bennett et al. 2019; Apetrei et al. 2021). Today, a variety of Indigenous resource management systems, often rooted in locally deep histories of engagement with island environments, are recognized for their critical role in responding to contemporary conservation challenges. Across the Pacific Islands, sustainable management and conservation of ecosystems increasingly involve strategies integrating ILK and deeper engagement of local communities (Jupiter et al. 2014, Delevaux et al. 2018, Artelle et al. 2019), for instance by setting up culturally articulated restriction zones in order to better regulate marine resources (Cinner and Aswani 2007) as is the case with Bul in Palau (Ueki 2000, Carliste and Gruby 2018) or Reimaanlok in the Marshall Islands (Baker et al. 2011). Such initiatives develop protected areas with the involvement of local communities to integrate their specific needs, values and cultural heritages. However, research gaps remain including how to navigate such developments given the risks of conflicts between or accommodations of Indigenous and conservation and sustainability sciences within management or governance actions and practices.

This synthesizing challenge is of material contemporary concern in French Polynesia where the resurgence of a traditional management practice referred to as rāhui (Bambridge 2016), has become centered for the work of communities to exert agency over their marine resources' ecological futures (Mawyer and Jacka 2018). In this paper, we focus our attention on contemporary rāhui in Tahiti's Taiarapu peninsula, whose governance and management has been informed both by Indigenous Mā'ohi expertise, values, and practices - which we identify as a practice of Indigenous conservation - as well as by conservation and sustainability sciences. By Indigenous conservation, we mean the historically empirical, expert environmental and ecological practical knowledge of Tahitian and Mā'ohi peoples culturally grounded in the worldview of their communities towards sustainable ecological futures. In that sense, rāhui is a critical example of Indigenous conservation which reflects local and place-based marine management practices, sometimes considered "traditional" in comparison to universal/conventional conservation-based knowledge and expertise derived from the biological and ecological disciplinary sciences common to management system toolkits in Marine Protected Areas (MPAs).

\footnotetext{
${ }^{1}$ All the terms in Tahitian are written following the orthographical conventions of the Tahitian Academy with the exception of place names, which are written in their everyday representation.
} 
Deeply rooted in the sociopolitical and religious dynamics of chiefly governance of marine and terrestrial resources before the French colonial era (Nordhoff 1930; Bambridge, 2016), rāhui has reemerged on the Taiarapu coast as a potent tool for the conservation of marine resources, especially in nearshore coral reef environments where intensive fishing pressure, particularly in more populated areas, has led to substantial declines in many highly prized and vulnerable species (Friedlander et al., 2016; Thiault et al., 2019). Historically, Mā‘ohi communities have established relations of continuity between land and marine tenure, resulting in systems of priority and specialized control of territories and resources (Bambridge 2009, 2016, Le Meur et al. 2018). In the 19th and 20th century ethnographic literature, rāhui was considered a fundamental institution in Tahiti with relational practices between different individuals or groups within Tahitian society and with entities charged with sacredness inside an environmental network (Rigo 2004) and closely linked to conceptions and practices of tapu (Shore 1989, Rigo 2016). Today, the resurgence of Tahitian rāhui raises questions about the place of ecological thinking, conservation and sustainability sciences, management and governance, as ethos and as practice, within community-driven and community-led conservation actions. As Indigenous peoples and local communities (IPLCs) negotiate 'usness', relationships, and interactions with nature and its resources in a changing world upon a foundation of culturally-grounded and place-based values (Whaanga and Wehi 2017), the need to attend to community understandings including beliefs around, valuations of, feelings about, or expectations and hopes for the role of conservation and sustainability sciences within their planning, decision- and policy-making processes is an immediate concern.

Here, we assess how such synthesis should take into account the distinct conceptions, perceptions, and expectations (CPE) of two Taiarapu communities, Teahupo'o and Tautira, around the role of conservation and sustainability sciences and scientists to support effective community-based biodiversity conservation and natural resources management. By demonstrating both the presence of, as well as differences between, local communities' CPE mediating conservation sciences' role in a community's plans and actions, we suggest that sensitive attention to CPE can help bridge the gap between science, management and decision-making (Tadaki et al., 2017; Van Riper et al., 2020). To understand how both Indigenous and conservation and sustainability practitioners can better understand one another and work together, we ask the following questions: How do IPLC stakeholders feel about Indigenous conservation approaches as related to approaches grounded in conservation and sustainability sciences? How do they define the role of marine and environmental sciences in the context of community-led governance? What is a community's sense of the place of conservation in the planning and enactment of rāhui governance? Are local stances towards science or conservation the same at different rāhui sites and what might differences say about achieving sustainable management goals? To answer these questions, we explored how conservation is materially dealt with in situ in contemporary rāhui governance on Taiarapu.

\section{Methods}

\section{Fieldwork}

Teahupo'o and Tautira are two distinct districts on Tahiti's Taiarapu coast (Figure 1). They are respectively located on the western and eastern sides of the southern coastline but converge on an area called Fenua 'Aihere (lit. uncultivated land, in French 'la brousse') which has been under a conventional preservation law since 1952 dedicated to protection of sites of cultural, archaeological, historical, and legendary interest. This remote area, nearly 2000 hectares with no roads and only accessible by boat, is also home to contemporary 
communities which primarily live by subsistence fishing and farming (Table 1). Both of the

138 rāhui areas we studied are located in the Fenua 'Aihere. Though composed of the same extended families, Tautira and Teahupo'o have maintained a rivalry rooted in what Samoan historian Damon Salesa refers to as a type of Indigenous deep time (Salesa 2014). Each has composed and developed its own rāhui area with community-specific rules. Teahupo'o was the first district to re-establish rāhui, to address a decline in fishing productivity and protect themselves from outsider fishermen (including from Tautira). The rāhui of Teahupo'o was officially implemented in 2014 and legally registered within the $6^{\text {th }}$ category of French Polynesia's Environmental Code with the appellation "Marine Managed Natural Resource Area." Inside an area of 768 hectares, all activities (e.g. fishing, swimming, navigating, collecting resources) were prohibited for three years (Figure 1). In 2017, the prohibition was extended for three more years and the closure was renewed again in 2020. As a consequence, the protected area has not been "opened" for seven years. Administratively, the rāhui of Teahupo'o is managed by the Department of Environment, the Territorial state agency that oversees environmental domains including the preservation and management of natural resources (through the Environmental Code). Somewhat differently, the nearby community of Tautira implemented a rāhui in 2018 with a three year closure plan. In this case, the rāhui is legally registered through the Fishery Code with the appellation "Controlled Fishing Area". In Tahiti's post-colonized administration, fisheries have separate governance from other environmental domains and the Department of Marine is the responsible state agency. The rāhui at Tautira only prohibits fishing activities and is subdivided into three zones with a fully closed central area - a puna (source) — as the heart of the functional system (Figure 1). Notably, the rāhui at Teahupo'o and Tautira were both locally conceived to be for a limited period, but the legally established protection supported by the State appears to be a permanent designation. That any opening plan will thus need to be validated by the State is a persistent reminder of the governance tensions inherent in legal pluralisms around marine resource management (Bambridge 2016).

Each state agency is responsible for scientific monitoring of its associated rāhui. However, a collaboration between the European INTEGRE (INitiative des TErritoires pour la Gestion Régionale de l'Environnement) program for the development of integrated management of coastal environments, and the Fondation de France program on reef resilience, meant that scientific ecological monitoring of reef species was undertaken around Taiarapu by researchers from CRIOBE (Centre de Recherches Insulaires et Observatoire de l'Environnement, French Polynesia) in July 2016, January 2017, and December 2019. These periods of monitoring established visible feedback loops between disciplinary sciences informing the communities in their rāhui governance and management and communities informing scientists about place-based and culturally-grounded beliefs and values that support the success of rāhui based marine protection. 


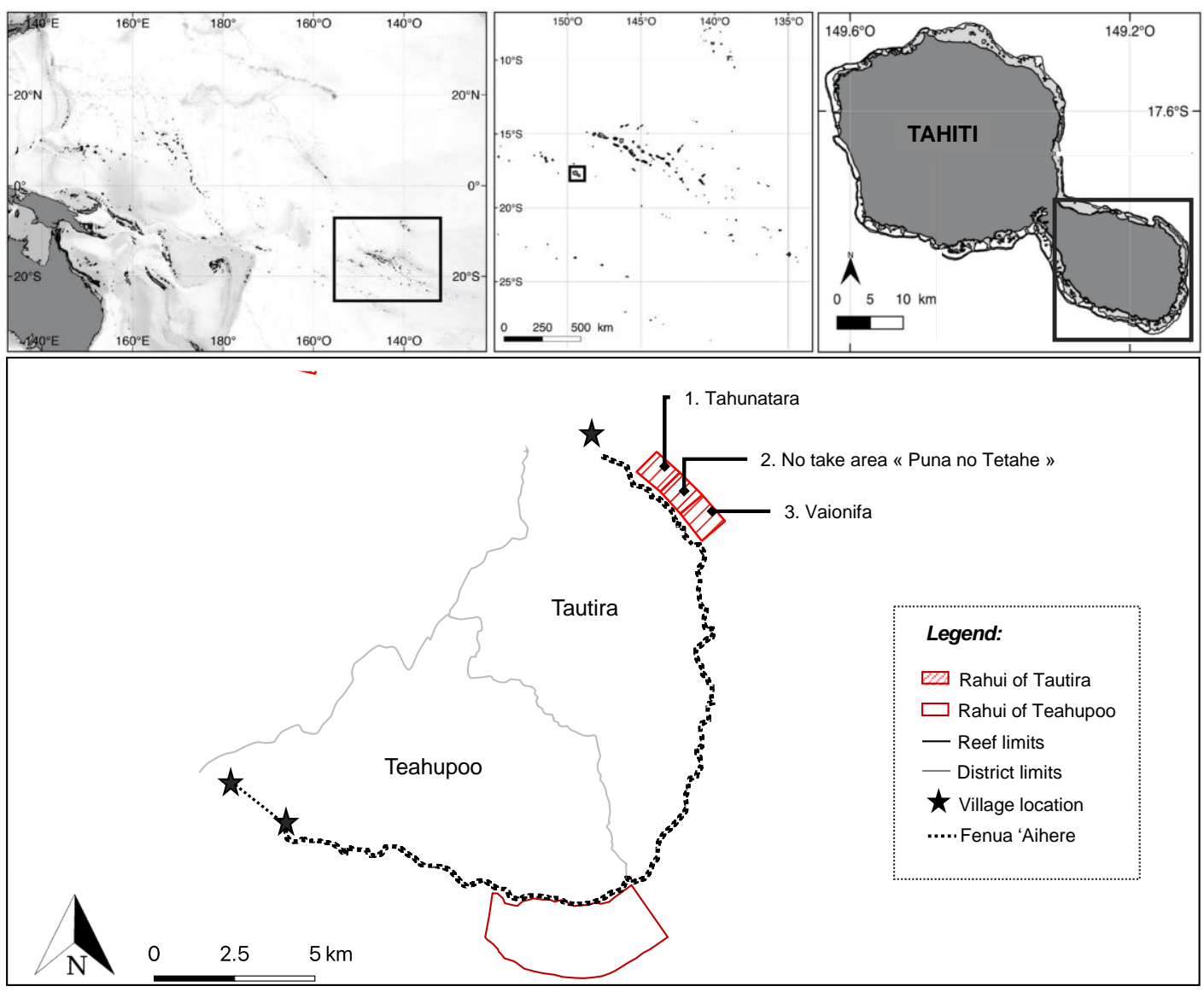

178 Figure 1 Fieldwork in Taiarapu: location of the studied rāhui areas at Tautira and Teahupo'o.

180 Table 1: Details of population, fishing dependence for local communities and rāhui at Tautira 181 and Teahupo 'o $\mathrm{o}^{1,2,}$

Total Population

Tautira

$2,249[10.8 \%]$

Number of inhabitants [\% of

Taiarapu]

\section{Population ( $>15$ years)}

Number of inhabitants [\% of

Taiarapu]

Gender

Women [\% of district]

Men [\% of district]

Fishing activities

Fishermen [\% of Taiarapu]

Fishermen [\% of district]

Other activities

Farming [\% of district]

Others [\% of district]

Without activity [\% of district]

\section{Rāhui}

Type

Surface

Official initiation time

Description

$$
1,883 \text { [11.7\%] }
$$

$940[49.9 \%]$
$943[50.1 \%]$

$$
\begin{gathered}
725[30 \%] \\
725[38.5 \%] \\
\\
87[4.6 \%] \\
730[38.7 \%] \\
1,004[53.3 \%]
\end{gathered}
$$

Periodic Harvested Closure 265 ha

Since 2018

Area subdivided into 3 zones

Prohibition of all fishing activities
1,120 [6.7\%]

547 [48.8\%]

573 [51.2\%]$$
195 \text { [15\%] }
$$$$
195 \text { [17.4\%] }
$$$$
60[5.4 \%]
$$$$
421[37.5 \%]
$$$$
585 \text { [52.2\%] }
$$

\section{Teahupo'o}

1,419 [6.8\%]

ic Harvested Closure

767 ha

Since 2014

One entire area

Prohibition of all activities 
${ }^{1}$ ISPF 2012, 2017; ${ }^{2}$ Marines Resources Department of French Polynesia (DRMM); ${ }^{3}$ Environmental Department of French Polynesia (DIREN).

Because the inhabitants of Fenua 'Aihere live a subsistence lifestyle, they regularly fish by the seaside and generally respect the rāhui which they have established. A distance of 50 meters (Teahupo'o) and 100 meters (Tautira, due to important maritime traffic) offshore allows community members to continue their activities on the coast. Beyond this distance, rāhui rules come into effect. Governance and management of rāhui is carried out by a management committee, the tōmite rāhui, which brings together all community stakeholders including the mayors (tāvana), the representatives of local associations (environmental protection, fishermen's cooperative, surf, culture, education, etc.), a representative of each prominent religion, and representatives of the corresponding State protection agency (Environmental or Fishery Department). The tōmite ensures functioning and surveillance of the rāhui. In practice, it is the people of Fenua 'Aihere who maintain local surveillance of the area. They watch for rāhui infractions and alert the tōmite when action is warranted.

\section{Study framework}

Following Aswani et al. (2017) and Bennett et al. (2017), we approached the role of the social sciences in advancing conservation science by applying methods drawn from anthropology, psychology, and cognitive science to study the rāhui of Teahupo'o and Tautira in the context of near-shore community-led Indigenous resource management. Our methodology highlights the idea of "conservation social science" (Mascia et al. 2003, Newing et al. 2011, Bennett et $a l .2017)$ to refer to diverse practices drawing upon social science epistemologies and methods to understand Indigenous science (Morishige et al. 2018) and local conservation policy, practice and outcomes (Bennett et al. 2017, Bennett 2019; Moon et al. 2019a).

To answer our questions, we drew on naturalistic inquiry (Guba and Lincoln 1982, Lincoln 2007) to develop a theoretical framework around Teahupo'o and Tautira communities' and conservation or sustainability scientists' concepts, perceptions and expectations (CPE) for the rāhui tool. Perception is the ability to see, hear, or become aware of something through the senses (Bonnet et al, 1989). It is not an immediate image of the world (Barrow and Tenenbaum 1986) but includes prior knowledge, expectations, experiences, and motivations to help give meaning to sensory data. Prior work suggests that perceptions are useful indicators of marine conservation goals (Gelcich et al. 2008, Abecasis et al. 2013, Bennett and Dearden 2014, Jefferson et al. 2014, Beyerl et al. 2016, Bennett et al. 2019). However, previous work in conservation science has rarely focused on conceptions. Conception loosely refers to the ability to form an understanding in the mind of objects or processes in the world (c.f. Moon et al. 2019b). While the literature engaging the relationships between perception and conception is quite vast, with roots, trunks, and branches in numerous disciplines including anthropology, cognitive science, linguistics, neuroscience, philosophy, and psychology, a critical hinge rests in the observation that people do not perceive primarily with their senses, but with their minds, famously about such apparently objective natural entities as color (Berlin and Kay 1991) or biological kinds (Conklin 1998). Finally, we elicited community members' expectations for the rāhui. Expectations, we hypothesized, inform and reflect community members' hopes and desires but also their doubts, anxieties, and historical wounds. Such information is crucial to develop adequate and appropriate conservation measures well-linked to local scales including the practical achievement and success of conservation and management actions. 
Practically, we identified CPE in individual interviews by coding discursive moves that indicated the speaker's conceptual, perspectival, or expectational stance vis-à-vis rāhui and the seascape, conservation science, and coral reef management and conservation practices. Since individuals live in a social environment characterized by interactions and relations, we also wanted to be aware of the impact of social groups on CPE. In a sense, rāhui is a form of social thinking and shared knowledge that guides different ways of interpretation toward shared positions (Jodelet 1989) and reflects Indigenous science (Morishige et al. 2018) and local values around and orientations toward the social. The social context of CPE was studied through meeting participation and collective discussion. All the elements that inform CPE according to sociogeographically situated stakeholders are represented on a diagram in Figure 2 .

\section{Data collection}

Initial data collection took place during a 10-month research period from February to November 2017. During this time, the science team in which we participated was responsible for supporting and facilitating the contemporary rāhui projects around Taiarapu in collaboration with scientists from CRIOBE alongside the administrative support of the government of French Polynesia. Because the rāhui of Teahupo'o was introduced in 2014, the dynamic of rāhui management was already underway prior to the survey. Escorted by a key partner-locally respected as a Tahu' $\mathrm{a}^{2}$ (expert) across many areas such as navigation, fishing, agriculture, medicine, among others-we interviewed 11 local stakeholders and participated in three tōmite meetings. In Tautira, data-collection was different as there were no rāhui in 2017. However, we were present for the emergence of a community-led push for rāhui here as well due to the actions of several local tāvana (mayors) who invited CRIOBE scientists and others involved in the rāhui at Teahupo'o to lead a series of meetings exploring the possibility of a rāhui in this community. In this context, we interviewed 10 local stakeholders and led nine meetings at Tautira village and communities in the Fenua 'Aihere (the southernmost coast of Tahiti island beyond the end of the road-access here requires travel by sea for visitors and community members alike) to share knowledge and address their expectations. During a final meeting, the community decided to adopt a rāhui framework for Tautira. In this context, the role of CPE in facilitating a better preparation for planning a rāhui implementation was evident and it was clear that neglecting CPE would be a risk when defining a management plan which depended on local buy-in.

Data collection continued from September 2018 through June 2019, a 10-month consecutive research in place. This longer period allowed us to collect deeper information on the recent rāhui implementation at Tautira with a new round of interviews. For each interview, we brought a visual image of the rāhui area (with a flyer) to support the discussion and to improve mutual understanding of individual CPE linking rāhui and engagements with conservation and sustainability sciences and practitioners, sometimes also supporting the State and its administrative agencies. In total, during this period we conducted 15 interviews and participated in six meetings at Teahupo'o, and we conducted 21 interviews and observed two meetings in Tautira. Across these contexts we sought to document the plurality and diversity of views and the complexity of individual expectations evidenced in meeting and interviews. Examples of local communities' CPE mediating Indigenous and conservation and sustainability sciences approaches is presented in Table 2.

\footnotetext{
${ }^{2}$ Tahu'a: Specialist or expert in one domain. Example: tahu'a pure (priest), tahu'a tahutahu (sorcerer), tahu'a rā'au (traditional medicine man), etc., online dictionary of the Fare Vāna'a (Tahitian Academy).
} 


\section{Results}

According to stakeholders, conceptions, perceptions and expectations (CPE) progressively diverge between local community world views and values and administration representatives along a gradient of conceptions to perceptions and expectations. Conceptions observed highlighted the evolution and adaptation of rāhui as a cultural practice as evidenced in Indigenous approaches to seasonality, the continuum of the land/sea concept, harvest opening periods, and conventional approaches to fishing prohibition, rules and law (like any other MPA). When local community CPE align or do not align with the rāhui framework, the perceptions of who benefits or how the rāhui operates illuminate important facets of Indigenous and community roles in governance relative to other marine protection schemes. For instance, a reciprocal sense of belonging appears as a critical divergent element vis a vis other marine protections. As locally conceived, it is up to the communities who establish rāhui to determine who is targeted for benefits, for instance local fishermen, thus emphasizing a reciprocal identity between community and rāhui. Another divergent element is the role of tōmite management as a legitimate local community entity, versus the viewpoint of State agencies that members of tōmite only have a consultative opinion. Notably, though rāhui practice is deeply rooted in Mā'ohi culture, CPE also show common foundational perceptions around the intersection of human and environmental well-being and expectations about the efficiency of surveillance, compliance with rules and community involvement.

Sociogeographical conceptions that link rāhui to Indigenous science and conservation are similar in Tautira and Teahupo'o and include four key ideas: (i) restriction, especially of fishing activities, (ii) protection of coral habitats, (iii) the importance of seasonality, founded on knowledge, skill, or experience and (iv) the goal of (re)production for reef species. Those conceptual ideas and strategies are set up to achieve Indigenous conservation goals including asserting the legitimacy of the cultural practice and application of rāhui, sustainable fishing practice, and the maintenance of local maritime territoriality highlighted by local knowledge and authority over decisions regarding rāhui. The rāhui tool is used at both sites in a context of fish rarity and is tightly associated with the idea of the necessity of regenerating reef species by stopping fishing from outsiders and finding solutions to lagoon fishermen's difficulties; thus, the fishing ban. But such conceptions here lead to divergent perceptions and expectations about the rāhui at Tautira or Teahupo"o (Figure 2). 

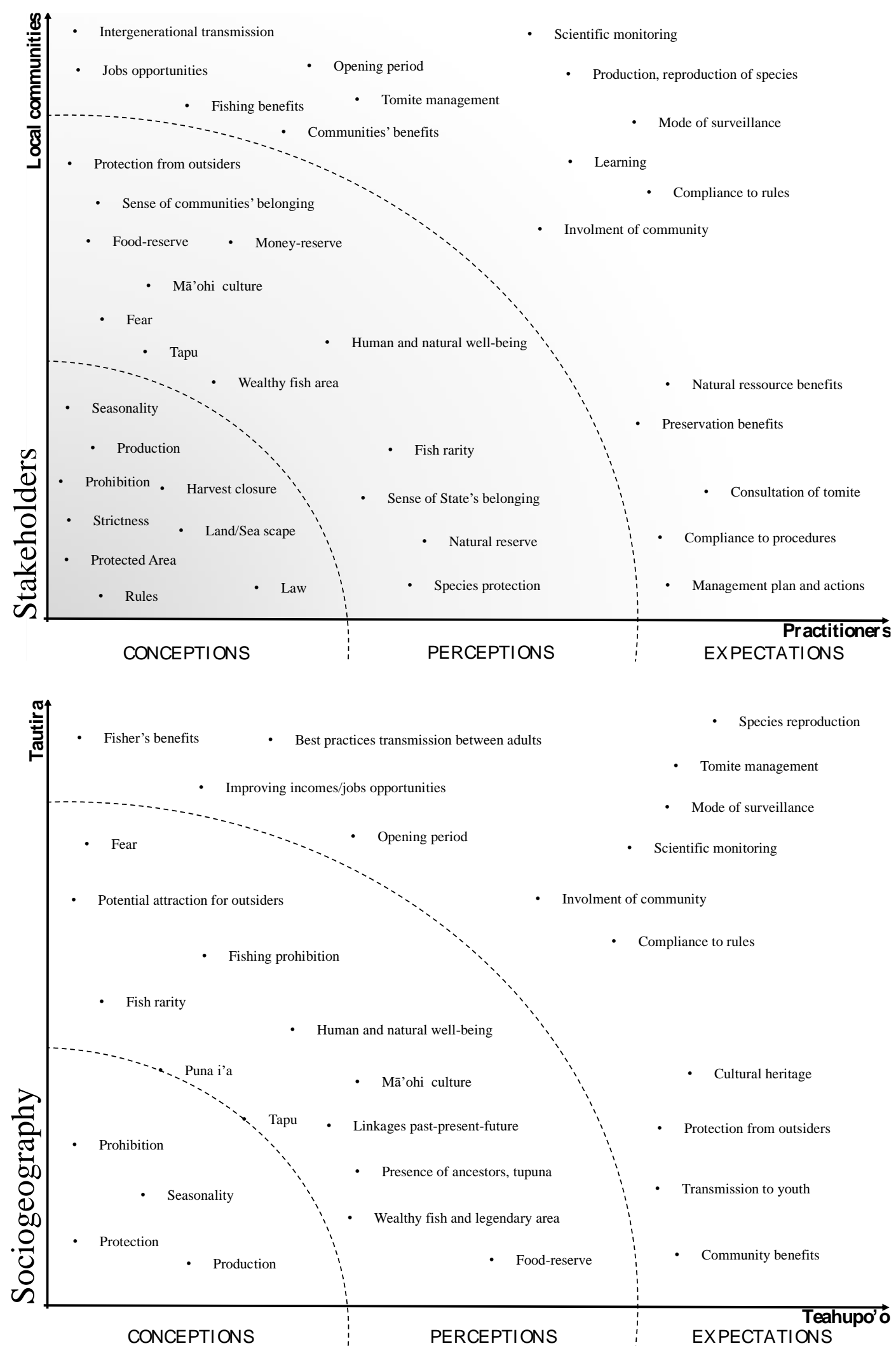

316 Figure 2: Diagram of the CPE model of rāhui according to stakeholders (local communities vs 317 administrative practitioners - upper panel) and the local sociogeographical situation (in

318 Tautira vs Teahupo'o - lower panel) 
Results show that rāhui actions for conservation highlight the importance of culturallygrounded and place-based values. Indeed, we observe that stakeholders in Tautira sometimes compared rāhui as a protection tool to Marine Protected Areas (MPAs), a distinctly contemporary and post-colonial form of permanent and unbroken conservation. But we observe in situ that rāhui may be expected to feature open seasons for harvest or even the end of a fishing ban.

Interestingly, stakeholders expressed some anxiety about their own relationships to the freshly established rāhui. It was not clear if informants fear a permanent designation as an obstacle to their own harvesting rights or if anxiety or fear around the term rāhui is due to its connections with invisible and potentially dangerous spiritual or more-than-human presences in the Fenua 'Aihere (similar to dynamics seen in the Marquesas or elsewhere across Polynesia (Donaldson, 2018; Donaldson, 2019). However, we observed from key informants that the historical and cultural power of rāhui seemed less activated in Tautira, where people were more concerned with the fishing implications. Others underlined the importance of seasonality, and not just about opening and closing seasons but also ideas rooted in Indigenous biological knowledge of reef species. In Teahupo'o, the importance of legends, ancestors, and history related to rāhui and its geographical place point to expectations strongly geared towards cultural transmission, benefits to the community of Teahupo'o, and protection against outsiders. Nevertheless, at both sites, Mā'ohi interest in biological conservation appears to be read through a cultural framework wherein enhancing the resource goes hand in hand with the development (tupu) of cultural agency and futurity. The CPE fronted a desire to culturally-ground activities through tapu (in this case, sacred restriction as one of the mechanisms of the rāhui) to preserve natural resources for transmission to future generations. Notably, a stance toward protecting the community from outsiders by adapting the rāhui tool to mobilize conventional conservation approaches - i.e. through a legal appellation of rāhui based on existing legal frameworks that in reality do not adequately map onto pre-colonial practices - was also evident within the CPE.

The different results in CPE in Tautira highlight the non-homogeneity of community-led Indigenous resource management (Figure 2), where the most important activity is fishing and $30 \%$ of the population are professional lagoon fishers, versus $17 \%$ in Teahupo'o (Table 1). The rāhui ban on fishing therefore is perceived as risking decreased harvest and promising further difficulties to come. As can be seen in Table 1, more than half of the inhabitants in both districts are not employed in the formal labor sector. Thus, most of the informants in Tautira expressed some worry about rāhui, from a fear that reopening marine areas for fishing would be repeatedly deferred, as at Teahupo 'o, or that the area would attract more outsiders in response to the productive (conceptual) nature of rāhui (puna, reproduction of species) which would also be detrimental for local fishermen. Expectations here were therefore oriented towards a better yield for the fishermen of Tautira and an improvement of their income. The strict objective of natural resources conservation inscribed in the fisheries code and the ZPR principle in the case of Tautira locally reads as a way to improve fishery yields. However, we note common elements in Figure 2 (perceptions of human well-being, expectations of a successful area for fish reproduction, surveillance and compliance with rules, monitoring of results) that link rāhui to conventional approaches of conservation. As can be seen in Table 2, local feelings about Indigenous and conservation sciences approaches strongly support the development of pathways to better integrate approaches through sensitive alignment to local CPE. 
"The rāhui, it has always existed since the ancestors, and all Tahitians know the rāhui ... If there are still grandparents who are living here, we are able to ask them to explain what is the rāhui." (Pāpā'ū, Teahupo'o)

"Te 'opani e tai' a te o tau... you have to stop when there are laying seasons, that's the rāhui. There are seasons. Now, rāhui, people understand as something which lasts for a long time. No ... there are seasons, like before." (Ancient

Fisherman from Taiarapu)

Selection of

Quotations

"Rāhui is rāhui. It is not a MPA." (Teahupo`o leader of Rāhui Tōmite)

"This is the Tahitians' fault. Ah 'aivāna'a ... that means scientists ... understand ... you see, they don't want to know ... after they say ... huh, looking for money for them ... No! They came to inform us, and maybe our children could work with them, in collaboration." (Mama from Taiarapu)

"The rāhui is to protect but also to produce." (Tautira Fisherman).

"The rāhui is [for] the community's engagement, it is required to open for the communities" (Teahupo 'o leader of Rāhui Tōmite)

"The rāhui belongs to the communities. Fenua 'Aihere people are doing surveillance. Even Teahupo'o fishing boats, when they go fishing. When they see people in the rāhui, they call the city hall, squarely at the city hall [...] Every day. There is a grandma who lives in Fenua 'Aihere with her daughter, her children and her mo 'otua (grandchildren). When they see, they call the city hall." (Tahu'a, Teahupo'o)

Local Maintaining the spirit of the traditional rāhui, honoring the

Understanding invisible presence of ancestors, preserving regular/occasional

Understanding opening as an IRM practice, cultural conservation as integral Objectives to a local Tahitian subsistence lifestyle.

"They are the ones who will inform their parents, so that they respect the lagoon, because here, almost all the parents are fishermen." (local MEA referent, Tautira)

"I can't open if I don't know about the reproduction inside the rāhui." (President of Rāhui Tōmite of Teahupo'o)

"We never see scientists coming from Environmental Department. You know the team here [from CRIOBE], they are in the field. And because I'm also in the field, you have to evolve like that. If not, what is the word you gave? Indeed, the word you gave to the fishermen, you have to support ... This is what the fishermen are expecting [...] The Environmental Department is the provider who comes without asking us and only they have the report. How can we evolve like that?" (Teahupo'o leader of Rāhui Tōmite)

Developing productive collaboration with on-the-field scientists by taking advantage from scientific methodologies and monitoring to transmit rāhui practice, addressing conflicts around the legal administrative framework that uses the cultural appropriation of the term rāhui to suit State conservation or management interests that diverge from local CPE. Better integrating Indigenous and non-Indigenous conservation approaches will benefit from attention to community CPE. 
The CPE of the two Taiarapu communities, Teahupo'o and Tautira, suggests that the integration of Indigenous conservation with conservation and sustainability sciences to advance the success of rāhui implementation could be advanced by sensitive attention to local communities' specific and, at times, divergent CPE mediating that integration. Supporting effective community-based conservation of biodiversity and management of natural resources should vigorously take into account the non-homogeneity of Indigenous and local communities' CPE around the role of conservation and sustainability sciences and scientists in decision-making and policy towards successful collaborations and desired outcomes. In particular, our study addressed four important questions.

\section{How do IPLC stakeholders feel about Indigenous conservation approaches as related to approaches grounded in conservation and sustainability sciences?}

Rāhui exemplifies a strong Indigenous, Oceanian, and Mā'ohi approach to conservation (Table 2). Its reemergence in French Polynesia, and particularly around the Taiarapu coasts provided a significant site for reflecting on how a conservation sciences approach to resource management and governance integrated with an Indigenous and community-led approach as long as the diverse conservation sciences practices support and align with local CPE. In the case of the rāhui at Taiarapu, conventional approaches to biological and ecological science were mediated by social scientists who had previously worked on the comprehension of place-based local needs with the communities in Teahupo'o and Tautira and were thus positioned to take into account not only the importance of ILK but the culturally-grounded CPE of stakeholders in integrating ILK within conservation planning and enactments. Thus, prior coordination between Indigenous and conservation and sustainability sciences approaches to conservation played a fundamental role in rāhui conception, design, and implementation. Over time, the mixed conservation approach grounded the practice of rāhui as an adaptation aligned with local CPE. Indeed, in Teahupo'o, the rāhui area embraced Mā'ohi culture and resulted in the perceived reimplementation of a Tahitian rāhui practice (essentially different from MPAs), which valued the presence of ancestors at sites on the cultural landscape like puna i'a (stone sites associated with particular species' seasonal management and use, Nordhoff 1930), and supported the institution and agency of the local rāhui tōmite. In Tautira, the rāhui implementation involved important relationships and interactions between local communities and scientists, which ultimately took root as arrangements defining the boundaries and design, objectives, expectations, and conditions of the protected areas to improve fishermen incomes. In the literature, such interactions are the foundation for tailoring coral reef management to local contexts in a way that acknowledges the importance of people's values (Kochalski et al. 2019, Thiault et al. 2020), local peer-topeer social networks (Christie et al. 2009), cultural ecosystems services (Chiesura and De Groot, 2003; Hicks et al., 2013; Satz et al., 2013), customary management (Cinner and Aswani 2007, McMillen et al. 2014, Delevaux et al. 2018), and local forms of territoriality (Roué 2012, Bambridge 2013; Donaldson 2019). As Aswani et al. (2015) demonstrated, ILK learning can inform and guide the requisite decision-making process and offer a practical way for management efforts to become more efficient. Here, we note that the incorporation of Indigenous and local knowledges with conservation and sustainability sciences can be further advanced by taking into account the CPE which mediate between these distinct epistemic cultures (Cetina 2009). Attention to the mediating roles of CPE at the local level can yield positive results and outcomes, as happened at Taiarapu. The most notable pessimistic feelings 
about a conservation sciences approach rest on ongoing legal framework contradictions that seem to categorize rāhui as MPAs whereas local community stakeholders do not agree.

\section{How do Mā'ohi and local communities understand and value marine and environmental sciences in the context of community-led governance?}

In the context of community-led governance, sharing marine and environmental dynamics such as monitoring or evaluation of rāhui with local communities is central to ensuring that the measures taken are effective. Around Taiarapu, the scientific ecological monitoring promised by researchers from CRIOBE is expected to produce useful knowledge. The distinct expert role of scientists is thus well-perceived and understood to contribute evidence of the (re)production of the conceptual function of rāhui for the rāhui tōmite. According to local communities, conservation and sustainability sciences require a strong emphasis on crossgenerational environmental education and awareness while training local users and officials in reef monitoring and peer-to-peer enforcement frameworks (Aswani et al. 2015). In Taiarapu IPLC stakeholders want to advance such environmental education through the rāhui practice (Filous et al. 2021). The resurgent rāhui here supports both Indigenous and conservation sciences approaches through cultural transmission to the young (Teahupo'o) and by improving fishing practices and evolving CPE (Tautira). In this context, establishing contemporary rāhui was followed by the recent implementation of Marine Educative Areas (MEA) in Teahupo'o and Tautira to raise awareness of the importance of coral reef protection and conservation among youths. The local MEA referents are actually local rāhui leaders who have regular relationships with conservation scientists. But to be fully accepted, scientists have to spend time on site with IPLC stakeholders to insure durability of rāhui comanagement development. Here, the legitimacy of scientists' approaches and ecological monitoring was accepted because methodologies were adapted for IPLC stakeholders to incorporate their beliefs and values. And yet, before rāhui implementation, conservation sciences methods did not engender trust, but suspicion. In Teahupo 'o and Tautira, it took several years to inspire trust between scientists and local communities. Mistrust was partly fueled, on one hand, by historical experiences and legacies of colonization, and on the other hand, by the belief of some individuals and communities that they will be the ones who will indirectly suffer the direct and indirect negative consequences of a protected area. Scientists must be exceptionally careful in their actions and words to change local perceptions about the social consequences of their interventions, but at the same time they should not hesitate to fully engage the predictive capacity of disciplinary sciences to help people adapt to a changing environment. In this case, direct threats to the sustainability of coral reefs were felt to be confronted by the establishment of partnerships in which Indigenous communities and scientists support each other's goals and share knowledge of biological and cultural resources in a mutually beneficial manner. Even without perfectly tailored legal frameworks supporting them, contemporary rāhui should be seen as an emerging, evolving community-based approach to natural resources management where co-management and integration of scientists' and users' CPE is an enabling condition for success (Di Franco et al. 2016, Bennett et al. 2019, Silva et al. 2021). All stakeholders have to work on adapting themselves during the different steps of rāhui implementation, management and monitoring.

\section{What is the community's sense of the place of an Indigenous conservation approach in the} planning and enactment of rāhui governance?

Legally, the enactment of rāhui governance in Taiarapu aligned the practice with the MPA goal of a permanently protected area to suit strong conservation interests. If the marriage of 
Indigenous and conservation and sustainability sciences approaches leads to agreement on, respectively, a rāhui ending at Teahupo'o, and a regular rāhui opening at Tautira, this will require changes to the ministerial decrees in which each rāhui is inscribed. During the previous meetings at both sites, local communities had the choice to collaborate with the State. As we can see in the recorded CPE, such a choice responds to important expectations of communities from Teahupo'o and Tautira who agree on respecting and complying with rāhui rules because they lay the foundation for sustainable future areas for fishing and a robust food reserve. This is only possible through developing efficient enforcement and surveillance of rāhui. The legal framework was actually supposed to support and respond to IPLC goals relative to CPE. However the absence of a specifically tailored law on rāhui or the State's official recognition of Indigenous management rights continues to be an obstacle to understanding between Taiarapu communities and conservation and sustainability science practitioners including representatives of state agencies. Local authorities can react in case of infractions but the outcomes of marine conservation and related management interventions depend to a large extent on community-scale compliance with these rule systems (Rohe et al. 2017) and require community engagement and enforcement (Goetze et al. 2018). In Taiarapu, such engagement comes from an Indigenous approach by developing and applying local, often informal, norms to protect rāhui. As shown in Table 2, despite conflictual relationships between rāhui tōmite and State environmental agencies regarding rāhui surveillance and the absence of an operational management plan, surveillance is locally organized for the rāhui of Teahupo'o by communities living at Fenua 'Aihere. In practice, local norms connected with rāhui prevail over State norms, including monitoring decisions between members of rāhui tōmite. For example, the procedure in Teahupo 'o for reef monitoring is to request authorization to access the rāhui area from the rāhui tōmite. This also requires separate authorization from the Department of Environment as the administrative manager of rāhui (and also members of tōmite). In accordance with CPE, ecological monitoring is locally used to inform fishermen about the efficiency of the rāhui in accomplishing the goals of many years of restriction.

Another example of the difficulties in considering Indigenous approaches to conservation is linked to the management role of the tōmite, which is basically to develop rāhui surveillance. Rāhui tōmite leaders argue that the presence of scientists doing fieldwork is important and has value for local communities, yet highlight tensions with state practitioners regarding monitoring. The tomite, with the support and the involvement of the residents of Fenua 'Aihere, because of their attachment to rāhui, prefer to organize the entire surveillance by themselves in their own way. Similarly, our interviews noted a series of misunderstandings and discordances between scientists and rāhui tōmite members over lack of local financial support, with problems of fuel reimbursement, leadership interventions, and the disappearance of markers. Thus, the role of tomite is at the heart of deeper social and cultural issues including trust and power relationships, post-colonial trauma, or post-colonial CPE, visible within contemporary rāhui contexts.

Are local stances towards science or conservation the same at different rāhui sites and what might differences indicate regarding achieving sustainable management goals?

Communities' stances towards Indigenous and conservation and sustainability sciences approaches differ in Teahupo'o and Tautira. In Teahupo'o, rāhui conception and implementation was the result of three years of deepening interrelationships between communities, social scientists, and state practitioners. Social science methodologies were used at first to understand how the territory was locally represented through exchanges on 
toponyms, legends, and Mā'ohi values around particular sites. This co-produced knowledge

519 between IPLC stakeholders and conservation sciences teams was used to support the community's own definition of rāhui boundaries and geography, grounded by a strong role for Mā'ohi culture. Thus the rāhui site is not just a protected area suiting foreign conservation interests but actively reaffirms politically sensitive cultural and territorial roots through local $\mathrm{CPE}$ about how to sustainably manage critical natural resources into the future, specifically, for future generations. Moreover, rāhui establishment also connects conservation and sustainability science practitioners to a set of informal norms and actions regarding local communities' values, e.g. those that strongly discourage fishing activity from fishers whose homes lie outside the district.

In the case of Tautira, both Indigenous and conservation sciences have also been at the heart of rāhui conception. The community was at first reluctant to implement any seascape protection because of the importance of fishing activities (Table 1). Local CPE in Figure 2 show the fear engendered by the term "rāhui" for fishers faced with need to maintain and improve their incomes. But to address the growing difficulties confronting nearshore fishermen, the inhabitants gradually supported the idea of establishing a rāhui in part of the lagoon. Based on recent experiences in Melanesia (Goetze et al. 2016, 2017, 2018, Carvalho et al. 2019), scientists presented to community members a theoretical model of rāhui that was in better alignment with local perceptions and expectations, with opening periods and rotations to ultimately help fishermen improve their harvest. The model was based on a central no-take area (puna no te Tetahee, Figure 1) which then feeds two other areas opened alternatively on either side of the puna. The alternating open areas would always be supplied by proximity to the no-take area. Communities in Fenua 'Aihere finally accepted this conceptual model of rāhui and the municipality of Tautira started a collection of signatures to justify the adoption of rāhui according to the theoretical ecological model. In a sense, the rāhui model in Tautira is an adaptation integrating Indigenous and conservation and sustainability sciences approaches with a rotative closure within the permanent puna area. It will concretely provide more local autonomy over fishing activities, which are expected to improve the income of fishermen and, more broadly, help them cope with environmental changes. In this context, bridging scientific and Indigenous knowledge highlighted the importance of trust-building and community involvement in all stages of research (Bizzarri and Czerny 2015, Silva et al. 2021), and the importance of shared interests in project objectives, settings, and outcomes (Apetrei et al. 2021).

Though deployed in support of the application of public policies, conservation and sustainability sciences thus become a tool serving the interests of IPLC stakeholders as well as national, regional, or global conservation ecology interests. Fundamentally, the application of the rāhui system, despite the evolution of culturally-grounded CPE, evidenced that culturally-grounded Indigenous resource management is a highly valuable tool supporting more balanced integration and exchange between stakeholders. At both sites, local expectations include the means to carry out surveillance, such as boat access, fuel costs, and job opportunities. Such local efforts for protection strongly produce better compliance with rules and conservation in rāhui areas. Importantly, in Tautira efforts from the State agencies to develop rāhui in collaboration with IPLCs is also envisioned as a springboard to introduce management tōmite inside current legal frameworks and to highlight the need to establish legal rights for local rāhui development. Regarding achieving sustainable management goals and conservation planning in the Anthropocene, we observe an evolution from the precolonial form of rāhui as an optimization of fish stock by "prohibition for postponed consumption" that fed island societies for hundreds of years, towards the contemporary rāhui 
as optimization of fish stock for sustainable resource management "not necessarily postponed". Critically, the contemporary practice also conserves potent cultural conceptions about the sacred, about place, as well as responsibilities to maintain and transmit culture

\section{Conclusion}

Resurgent rāhui in French Polynesia are fostering new mechanisms as customary law and traditional forms of marine resource management and governance are woven into contemporary actions. By inviting social scientists, ecologists, and State resource managerial institutions to assist in implementing rāhui, communities and local political initiatives are hybridizing (Fabre et al., in prep) Indigenous and conservation and sustainability values and sciences. Such governance systems are meant to directly respond to local desires to develop place-based, culturally-grounded and community-based management of marine resources, supported by conventional conservation approaches (Aswani and Ruddle 2013, Aswani et al. 2017, Sterling et al. 2017, Morishige et al. 2018, Eckert et al. 2018). In this context, local communities are emerging as leaders in contemporary resource management based on Indigenous knowledge relative to rāhui (Bambridge et al. 2019).

By fostering new hybrid mechanisms, rāhui in Taiarapu demonstrate the strengths of integrating Indigenous and conservation and sustainability sciences approaches into resource management and governance. The ways that resource management approaches are perceived, conceived, expected, and experienced in situ by local and other stakeholders, concretely mediates the integration pathways for disciplinary sciences and models within community-led conservation actions. Moreover, examination of these dynamics through our CPE framework shows and that the dynamics of community-led rāhui governance for resource management or conservation action evidence the material importance of place-based and cultural values. Importantly, our findings revealed the non-homogeneity of community-led Indigenous resource management. In one instance we saw how a conservation sciences approach in alignment with rāhui broadly addressed issues of culture and territoriality and, in the other, we saw how rāhui was taken to primarily support the local fishing economy. However, in both cases, contemporary rāhui involve conservation and sustainability sciences approaches in the plans and actions of local communities, despite the foundational role of Indigenous approaches to management. Such interactions produce an adaptive knowledge of nature as a self-constructive activity based on the construction of a "we" (Bambridge, D'Arcy, and Mawyer 2021) where all parties need to be understood to better align goals and social contemporary expectations. This work further suggests the crucial role of the social sciences in rāhui conception and implementation. We highlighted how contemporary rāhui led by local communities can Indigenize and decolonize marine conservation efforts (Tuhiwai-Smith 1999) through ILK while conservation and sustainability sciences can still inform and guide the decision-making process and offer practical ways to be more efficient and better integration of all stakeholders. Community members' sensitive, diverse, and potentially shifting CEP around the ecological futures of their nearshore waters, offers distinct evidence that Indigenous management systems are adaptable to changing environments, seasonal and cyclical behaviors, and social conditions. Our analysis of the proposed synthesis between Indigenous and conservation and sustainability sciences approaches to reemergent rāhui practices in Tahiti thus highlights the importance of supporting, incorporating, and combining Mā'ohi science in Indigenous cultural renewal. 


\section{Acknowledgements}

We thank all the people of Teahupo'o and Tautira for their leadership in protecting the wellbeing of Taiarapu's coral reef systems, including all those who participated in our survey and especially Patrick Rochette and Eric Pedupebe as each site who helped navigate access to community members and their 'utuăfare (households) and the challenge of translation between Tahitian and French conceptions. We thank the Fondation de France, the National Agency of Research and Technology (ANRT), and Te Mana o Te Moana who support P. Fabre's doctoral research. We are grateful to the Direction des Ressources Marines et Minières and CRIOBE who provided support for data collection and meeting participation. We are particularly grateful for thoughtful, sensitive comments on an earlier version of this article by Kawika Winter.

\section{References}

Abecasis, R. C., Schmidt, L., Longnecker, N. and Clifton, J. (2013). Implications of community and stakeholder perceptions of the marine environment and its conservation for MPA management in a small Azorean island. Ocean and Coastal Management 84, 208-219.

Apetrei, C. I., Caniglia, G., Wehrden, H., and Lang, D. J. (2021). Just another buzzword? A systematic literature review of knowledge-related concepts in sustainability science. Global Environmental Change 68, 102222.

Artelle, K. A., Zurba, M. Bhattacharrya, J., Chan, D. E., Brown, K., Housty, J. and Moola, F. (2019). Supporting resurgent Indigenous-led governance: A nascent mechanism for just and effective conservation. Biological Conservation 240, 108284.

Aswani, S., Basurto, X., Ferse, S., Glaser, M. Campbell, L., Cinner, J. E., Dalton, T. Jenkins, L. D., Miller, M. L., Pollnac, R., Vaccaro, I. and Christie, P. (2018). Marine resource management and conservation in the Anthropocene. Environmental Conservation 45(2), 192-202.

Aswani, S., Mumby, P. J., Baker, A. C., Christie, P., McCook, L. J., Steneck, R. S., and Richmond R. H. (2015). Scientific frontiers in the management of coral reefs. Frontiers in Marine Science 2, 50.

Aswani, S. and Ruddle, K. (2013). Design of Realistic Hybrid Marine Resource Management Programs in Oceania. Pacific Science 67(3), 461-476.

Baker, N., Beger, M. McClennen, C., Ishoda, A. and Edwards, F. (2011). Reimaanlok: A National Framework for Conservation Area Planning in the Marshall Islands. Journal of Marine Biology.

Bambridge, T. (2009). La terre dans l'archipel des Australes, Etude du pluralisme juridique et culturel en matière foncière. Au Vent des îles: Tahiti.

Bambridge, T. (2013). Land and marine tenure in French Polynesia: case study of Teahupoo. Land Tenure Journal 2.

Bambridge, T. Ed. (2016). The Rahui: Legal pluralism in Polynesian traditional management of resources and territories. Page (T. Bambridge, editor). ANU Press: Canberra.

Bambridge, T., Chlous, F., D’Arcy, P., Claudet, J., Pascal, N., Reynaud, S., Rodolfo-Metalpa, S., Tambutté, S., Thomassin, A. and Virto, L. R. (2019). Society-based solutions to coral reef threats in french pacific territories. Regional Studies in Marine Science 29, 100667.

Bambridge, T., D’Arcy, P. and Mawyer, A. (2021). Oceanian Sovereignty: rethinking conservation in a sea of islands. Pacific Conservation Biology.

https://doi.org/10.1071/PC20026

Barrow, H. and Tenenbaum, J. (1986). Computational approaches to vision. Page in R. Boffk, 

L. Kaufman, and J. . Thomas, editors. Handbook of perception and human performance. John Wiley and Sons: New-York.

Bennett, N. J. (2019). Marine Social Science for the Peopled Seas. Coastal Management 47(2), 244-252.

Bennett, N. J. and Dearden, P. (2014). Why local people do not support conservation: Community perceptions of marine protected area livelihood impacts, governance and management in Thailand. Marine Policy 44, 107-116.

Bennett, N. J., Di Franco, A., Calò, A., Nethery, E., Niccolini, F., Milazzo, M. and Guidetti, P. (2019). Local support for conservation is associated with perceptions of good governance, social impacts, and ecological effectiveness. Conservation Letters 12(4), 110.

Bennett, N. J., Roth, R., Klain, S. C., Chan, K., Christie, P., Clark, D. A., Cullman, G., Curran, D., Durbin, T. J. and Epstein, G. (2017). Conservation social science: Understanding and integrating human dimensions to improve conservation. Biological Conservation 205, 93-108.

Berkes, F. (2017). Environmental governance for the anthropocene? Social-ecological systems, resilience, and collaborative learning. Sustainability 9(7), 1232.

Beyerl, K., Putz, O. and Breckwoldt, A., 2016. The role of perceptions for community-based marine resource management. Frontiers in Marine Science, 3, p.238.

Bizzarri, C. and Czerny, M. (2015). The Co-Production in Marine Protected Areas for Sustainable Management KEYWORDS: Marina Protected Areas, Co-production, Sustainable Development of Tourism in Marina Protected Areas, Management of Marina Protected Areas. The Open Access Journal of Resistive Economics 8(50), 2345-4954.

Bonnet, C., Ghiglione, R. and Richard, J. (1989). Traité de psychologie cognitive. Vol. 1 Perception, Action, Language. Dinod. Paris.

Carliste, K. M. and Gruby, R. L. (2018). Why the path to polycentricity matters: evidence from fisheries governance in Palau. Environmental Policy and Governance 28(4), 223235.

Carvalho, P. G., Jupiter, S. D., Januchowski-Hartley, F. A., Goetze, J., Claudet, J., Weeks, R., Humphries, A. and White, C. (2019). Optimized fishing through periodically harvested closures. Journal of Applied Ecology, 1-10.

Cetina, K.K. (2009). Epistemic cultures: How the Sciences Make Knowledge. Harvard University Press: Cambridge.

Chiesura, A. and De Groot, R. (2003). Critical natural capital: A socio-cultural perspective. Ecological Economics 44(2-3), 219-231.

Christie, P., Pollnac, R. B., Oracion, E. G., Sabonsolin, A., Diaz, R. and Pietri, D. (2009). Back to basics: An empirical study demonstrating the importance of local-level dynamics for the success of tropical marine ecosystem-based management. Coastal Management 37(3-4), 349-373.

Cinner, J. E. and Aswani, S. (2007). Integrating customary management into marine conservation.

Delevaux, J. M. S., Winter, K. B., Jupiter, S. D., Blaich-Vaughan, M, Stamoulis, K. A. Bremer, L. L., Burnett, K., Garrod, P., Troller, J. L. and Ticktin, T. (2018). Linking land and sea through collaborative research to inform contemporary applications of traditional resource management in Hawai'i. Sustainability 10(9).

Donaldson, E. C. (2018). Place, Destabilized: Ambivalent Heritage, Community and Colonialism in the Marquesas Islands. Oceania 1, 69-89.

Donaldson, E. C. (2019). Working with the Ancestors: Mana and Place in the Marquesas Islands. University of Washington Press: Seattle.

Eckert, L. E., Ban, N. C., Tallio, S. C. and Turner, N. (2018). Linking marine conservation 
and indigenous cultural revitalization: First nations free themselves from externally imposed social-ecological traps. Ecology and Society 23(4).

Fabre, P., Mawyer, A. and Bambridge, T. (n.d.). Gouvernance des rāhui en Polynésie française : un processus d'hybridation pour la conservation et la gestion des écosystèmes coralliens. Revue d'Anthropologie des Connaissances.

Di Franco, A., Thiriet, P., Di Carlo, G., Dimitriadis, C., Francour, P., Gutiérrez, N. L., Jeudy De Grissac, A., Koutsoubas, D., Milazzo, M Otero, M. D. M.. Piante, C., Plass-Johnson, J., Sainz-Trapaga, S., Santarossa, L., Tudela, S. and Guidetti, P. (2016). Five key attributes can increase marine protected areas performance for small-scale fisheries management. Scientific Reports 6, 1-9.

Filous, A., Lennox, R.J., Beaury, J.P., Bagnis, H., Mchugh, M., Friedlander, A.M., Clua, E.E., Cooke, S.J., Fuller, T.K. and Danylchuk, A.J., 2021. Fisheries science and marine education catalyze the renaissance of traditional management (rahui) to improve an artisanal fishery in French Polynesia. Marine Policy, 123, p.104291.

Friedlander, A. M. (2018). Marine conservation in Oceania: Past, present, and future. Marine Pollution Bulletin 135, 139-149.

Friedlander, A. M., Shackeroff, J. and Kittinger, J. N. (2016). Traditional marine resources and their use in contemporary Hawai'i. In T. Bambridge, editor. The Rahui: legal pluralism in Polynesian traditional management of resources and territories. ANU Press, Canberra.

Gelcich, S., Kaiser, M. J., Castilla, J. C. and Edwards-Jones, G. (2008). Engagement in comanagement of marine benthic resources influences environmental perceptions of artisanal fishers. Environmental Conservation.

Goetze, J., Langlois, T. Claudet, J., Januchowski-Hartley, K. and Jupiter, S. D. (2016). Periodically harvested closures require full protection of vulnerable species and longer closure periods. Biological Conservation 203, 67-74.

Goetze, J. S., Claudet, J., Januchowski-Hartley, F., Langlois, T. J., Wilson, S. K., White, C., Weeks, R. and Jupiter, S. D. (2018). Demonstrating multiple benefits from periodically harvested fisheries closures. Journal of Applied Ecology 55(3), 1102-1113.

Goetze, J. S., Januchowski-Hartley, F. A., Claudet, J., Langlois, T. J., Wilson, S. K. and Jupiter, S. D. (2017). Fish wariness is a more sensitive indicator to changes in fishing pressure than abundance, length or biomass. Ecological Applications 27(4), 1178-1189.

Graham, N. R., Gruner, D. S., Lim, J. and Gillespie, R. G. (2017). Island ecology and evolution: challenges in the Anthropocene. Environmental Conservation 44(4), 323-335.

Guba, E. G. and Lincoln, Y. S. (1982). Epistemological and methodological bases of naturalistic inquiry. Educational Communication \& Technology 30(4), 233-252.

Hicks, C. C., Graham, N. A. J., and Cinner, J. E. (2013). Synergies and tradeoffs in how managers, scientists, and fishers value coral reef ecosystem services. Global Environmental Change 23(6), 1444-1453.

Jefferson, R. L., Bailey, I., Laffoley, D., Richards, J. P. and Attrill, M. J. (2014). Public perceptions of the UK marine environment. Marine Policy 43, 327-337.

Jodelet, D. (1989). Les représentations sociales. Presses Universitaires de France, Paris.

Jupiter, S. D., Cohen, P. J., Weeks, R., Tawake, A. and Govan, H. (2014). Locally-managed marine areas: Multiple objectives and diverse strategies. Pacific Conservation Biology.

Kochalski, S., Riepe, C., Fujitani, M., Aas, Ø. and Arlinghaus, R. (2019). Public perception of river fish biodiversity in four European countries. Conservation Biology 33(1), 164-175.

Lauer, M. (2017). Changing understandings of local knowledge in island environments. Environmental Conservation 44(4), 336.

Lincoln, Y. S. (2007). Naturalistic Inquiry. The Blackwell Encyclopedia of Sociology.

Mascia, M. B., Brosius, J. P., Dobson, T. A., Forbes, B. C., Horowitz, L., McKean, M. A. and 
Turner, N. J. (2003). Conservation and the social sciences. Conservation Biology b(3), 649-650.

Mawyer, A. and Jacka, J. K. (2018). Sovereignty, conservation and island ecological futures. Environmental Conservation 45(3), 238-251.

McMillen, H.L., Ticktin, T., Friedlander, A., Jupiter, S.D., Thaman, R., Campbell, J., Veitayaki, J., Giambelluca, T., Nihmei, S., Rupeni, E. and Apis-Overhoff, L. (2014). Small islands, valuable insights: systems of customary resource use and resilience to climate change in the Pacific. Ecology and Society, 19(4).

McMillen, H., Ticktin, T., \& Springer, H. K. (2017). The future is behind us: Traditional ecological knowledge and resilience over time on Hawai 'i Island. Regional Environmental Change, 17(2), 579-592.

Le Meur, P.-Y., Bambridge, T., Degremont, M. and Rodary, E. (2018). Les espaces marins du Pacifique entre logiques de commun et d'accaparement. Revue Internationale des Etudes du Développement 2(234), 9-30.

Moller, H., Berkes, F., Lyver, P. O. B. and Kislalioglu, M. (2004). Combining Science and Traditional Ecological Knowledge: Monitoring Populations for Co-Management. Ecology And Society 9(3), 2.

Moon, K., Blackman, D.A., Adams, V.M., Colvin, R.M., Davila, F., Evans, M.C., Januchowski-Hartley, S.R., Bennett, N.J., Dickinson, H., Sandbrook, C. and Sherren, K., (2019a). Expanding the role of social science in conservation through an engagement with philosophy, methodology, and methods. Methods in Ecology and Evolution, 10(3), 294-302.

Moon K., Guerrero, A.M., Adams V. M., Biggs, D., Blackman, D. A., Craven, L., Dickinson, H., Ross, H. (2019b). Mental models for conservation research and practice. Conservation Letters 12, e12642.

Morishige, K., Andrade, P., Pascua, P., Steward, K., Cadiz, E., Kapono, L., \& Chong, U. (2018). Nā Kilo 'Āina: Visions of biocultural restoration through indigenous relationships between people and place. Sustainability 10(10), 3368.

Newing, H., Eagle, C. M., Puri, R. K. and Watson, C. W. (2011). Conducting research in conservation: Social science methods and practice. Conducting Research in Conservation: Social Science Methods and Practice. Routledge. London, New-York.

Nordhoff, C. (1930). Notes on the off-shore fishing of the Society Islands. The Journal of the Polynesian Society 39(2), 137-173.

Norström, A. V., Nyström, M., Jouffray, J. B., Folke, C., Graham, N. A., Moberg, F., ... \& Williams, G. J. (2016). Guiding coral reef futures in the Anthropocene. Frontiers in Ecology and the Environment 14(9), 490-498.

Plummer, R., Armitage, D. R. and de Loë, R. C. (2013). Adaptive comanagement and its relationship to environmental Governance. Ecology and Society.

Rigo, B. (2004). Altérités polynésiennes ou métamorphose de l'espace-temps. CNRS Editi., Paris.

Rigo, B. (2016). Tapu and kahui in the Marquesas. In T. Bambridge, editor. The Rahui: legal pluralism in Polynesian traditional management of resources and territories. ANU Press, Canberra.

van Riper, C. J., Lum, C., Kyle, G. T., Wallen, K. E., Absher, J. and Landon, A. C. (2020). Values, Motivations, and Intentions to Engage in Proenvironmental Behavior. Environment and Behavior 52(4),437-462.

Rohe, J. R., Aswani, S., Schlüter, A. and Ferse, S. C. A. (2017). Multiple drivers of local (non-) compliance in community-based marine resource management: Case studies from the South Pacific. Frontiers in Marine Science 4.

Roué, M. (2012). Histoire et épistémologie des savoirs locaux et autochtones De la tradition à 
la mode History and Epistemology of Local and Indigenous Knowledge: from Tradition to Trend. Revue d'Ethnobiologie 1.

Russell, J. and Kueffer, C. (2019). Island biodiversity in the Anthropocene. Annual Review of Environment and Resources 44, 31-60.

Salesa, D. (2014). The Pacific in Indigenous time. In Armitage, D. and Bashford, A. eds., Pacific Histories: Ocean, Land, People. Macmillan International Higher Education.

Satz, D., Gould, R. K., Chan, K. M., Guerry, A., Norton, B., Satterfield, T., ... \& Klain, S. (2013). The challenges of incorporating cultural ecosystem services into environmental assessment. Ambio 42(6), 675-684.

Shore, B. (1989). Mana and Tapu: a new synthesis. In Howard, A. and Borofsky, R., editors. Developments in Polynesian Ethnology. University of Hawai'i Press, Honolulu.

Silva, M. R., Pennino, M. and Lopes, P. F. (2021). Predicting potential compliance of smallscale fishers in Brazil : The need to increase trust to achieve fisheries management goals. Journal of Environmental Management 288, 112372.

Sterling, E., Ticktin, T., Morgan, T. K. K., Cullman, G., Alvira, D., Andrade, P., ... \& Wali, A. (2017). Culturally grounded indicators of resilience in social-ecological systems. Environment and Society 8(1), 63-95.

Tadaki, M., Sinner, J. and Chan, K. M. A. (2017). Making sense of environmental values: A typology of concepts. Ecology and Society 22(1).

Thiault, L., Curnock, M. I., Gurney, G. G., Heron, S. F., Marshall, N. A., Bohensky, E., Nakamura, N., Pert, P. L., and Claudet, J. (2020). Convergence of stakeholders' environmental threat perceptions following mass coral bleaching of the Great Barrier Reef Lauric Thiault. Conservation Biology.

Thiault, L., Kernaléguen, L., Osenberg, C. W., Lison de Loma, T., Chancerelle, Y., Siu, G., and Claudet, J. (2019). Ecological evaluation of a marine protected area network: a progressive-change BACIPS approach. Ecosphere 10(2).

Tuhiwai-Smith, L. (1999). Decolonizing Methodologies: Research and Indigenous Peoples. Zed Books Ltd.: New York.

Ueki, M. . 2000. Eco-consciousness and Development in Palau. University of Hawai'i Press. Whaanga, H., and Wehi, P. (2017). Rāhui and conservation? Māori voices in the nineteenth century niupepa Māori. Journal of the Royal Society of New Zealand 47(1):100-106. 